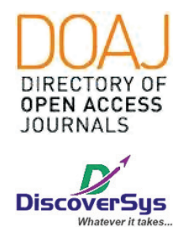

Published by DiscoverSys

\section{Karakteristik epidemologi ibu hamil dengan infeksi human immunodeficiency virus di RSUP Sanglah Denpasar periode Januari 2014 - Desember 2017}

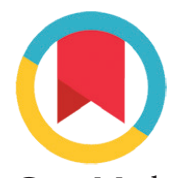

CrossMark

\author{
Komang Juni Artawan, ${ }^{*}$ I Wayan Artana Putra ${ }^{2}$
}

\title{
ABSTRACT
}

Introduction: The cumulative rate of AIDS in pregnant women in the world is reported to increase dramatically, giving the consequent increase in morbidity and mortality from mothers and children. The purpose of this study is to provide a descriptive picture of pregnant women with HIV in Sanglah Hospital Denpasar during the period January 2014 to December 2017.

Methods: This study used a descriptive retrospective design in the population of pregnant women with HIV in Sanglah Hospital Denpasar during the period January 2014 to December 2017.

Results: During the study period a total of 218 cases of mothers with HIV were obtained in Sanglah Hospital Denpasar, with the majority characteristics being $20-29$ years $(56.80 \%)$, with the most dominant parity being 1 (48.16\%), multipartner husband risk factors
(56.43), housewife occupation (63.76\%), origin of the area found in Jebmbrana Regency (20.64\%), referral origin of Jembrana Regional Hospital (24.31\%), age $>28$ weeks of pregnancy (47.70\%), duration of antiretroviral therapy $\geq 6$ months (55.51\%), clinical stage I (79.35\%), birth method of caesarean section (70.22\%), birth weight of children $>2500$ grams (82.58\%), experienced mild anemia ( $\mathrm{Hb} 9.5$ to $10.9 \mathrm{~g} / \mathrm{dL}$ ) (84.12\%), an undetectable viral load (66.7\%), and a CD4 count of 200-500/mm3 (49.08\%).

Conclusion: HIV prevalence in pregnant women which has an increasing trend in Bali requires more attention from all lines, not only from health workers, but government involvement and public education are needed to prevent new cases of pregnant women with HIV infection.
1PPDS-1 Obstetri dan Ginekologi, Fakultas Kedokteran, Universitas Udayana-RSUP Sanglah Denpasar, Bali-Indonesia

${ }^{2}$ Departemen/KSM Obstetri dan Ginekologi, Fakultas Kedokteran, Universitas Udayana-RSUP Sanglah Denpasar, Bali-Indonesia

*Correspondence to: PPDS-1 Obstetri dan Ginekologi, Fakultas Kedokteran, Universitas Udayana-RSUP Sanglah Denpasar, Bali-Indonesia Komang Juni Artawan, komangjuniarthawan@gmail.com

Diterima: $13-07-2020$

Disetujui: 20-07-2020

Diterbitkan: 01-08-2020

Keywords: HIV infection, pregnant women, prevalence, characteristics.

Cite This Article: Artawan, K.J., Putra, I.W.A. 2020. Karakteristik epidemologi ibu hamil dengan infeksi human immunodeficiency virus di RSUP Sanglah Denpasar periode Januari 2014 - Desember 2017. Intisari Sains Medis 11(2): 798-804. D0I: 10.15562/ism.v11i2.792

\section{ABSTRAK}

Pendahuluan: Angka kumulatif AIDS pada wanita di dunia dilaporkan meningkat secara dramatis, memberikan konsekuensi peningkatan akan morbiditas dan mortalitas dari ibu dan anak. Tujuan dari penelitian ini adalah memberikan gambaran deskriptif pada ibu hamil dengan HIV di RSUP Sanglah Denpasar selama periode Januari 2014 hingga Desember 2017.

Metode: Penelitian ini menggunakan rancangan retrosepktif deskriptif pada populasi ibu hamil dengan HIV di RSUP Sanglah Denpasar selama periode Januari 2014 hingga Desember 2017.

Hasil: Selama periode studi didapatkan total 218 kasus ibu dengan HIV di RSUP Sanglah Denpasar, dengan karakteristik mayoritas berupa 20-29 tahun (56,80\%), dengan paritas paling dominan adalah para 1 (48,16\%), faktor risiko suami multipartner $(56,43)$, pekerjaan ibu rumah tangga (63,76\%), asal daerah ditemukan Kabupaten Jebmbrana $(20,64 \%)$, asal rujukan RSUD Jembrana $(24,31 \%)$, usia $>28$ minggu kehamilan $(47,70 \%)$, lama terapi ARV $\geq 6$ bulan $(55,51 \%)$, stadium klinis I $(79,35 \%)$, metode kelahiran seksio caesaria (SC) $(70,22 \%)$, berat lahir anak $>2500$ gram (82,58\%), mengalami anemia ringan ( $\mathrm{Hb} 9,5-10,9 \mathrm{~g} / \mathrm{dL})(84,12 \%)$, viral load tidak terdeteksi $(66,7 \%)$, dan hitung CD4 200-500/mm $(49,08 \%)$.

Simpulan: Prevalensi HIV pada ibu hamil yang memiliki tren semakin meningkat di Bali membutuhkan perhatian lebih dari segala lini, tidak hanya dari tenaga kesehatan, namun keterlibatan pemerintah serta edukasi masyarakat sangat dibutuhkan untuk mencegah timbulnya kasus baru ibu hamil dengan infeksi HIV.

Kata kunci: infeksi HIV, ibu hamil, prevalensi, karakteristik.

Cite Pasal Ini: Artawan, K.J., Putra, I.W.A. 2020. Karakteristik epidemologi ibu hamil dengan infeksi human immunodeficiency virus di RSUP Sanglah Denpasar periode Januari 2014 - Desember 2017. Intisari Sains Medis 11(2): 798-804. D0I: 10.15562/ism.v11i2.792

\section{PENDAHULUAN}

Infeksi Human Immunodeficiency Virus (HIV) dan sindromanya Acquired Immunodeficiency Syndrome (AIDS) selama ini telah menjadi perhatian serius di seluruh belahan dunia. Wanita menjadi salah satu populasi yang tercepat menerima penularan penyakit ini. Angka kumulatif AIDS pada wanita di dunia 
dilaporkan meningkat secara dramatis. Perempuan usia reproduksi yang terinfeksi HIV semakin meningkat jumlahnya di seluruh dunia demikian pula di Indonesia dan Bali khususnya. Konsekuensi dari fenomena ini menyebabkan meningkatnya pandemi HIV/AIDS tentunya juga menyebabkan meningkatnya angka kematian ibu dan bayi. Terlambatnya deteksi dini yang nantinya terlambat dalam penanganan pemberian Antiretroviral. Perlunya tindakan pencegahan dan skrining awal dengan fokus Ante Natal Care. Data dan karakteristik ibu hamil dengan HIV sangat penting untuk diketahui untuk merencanakan program-program pencegahan penularan HIV/AIDS.

Adapun data di dunia saat ini menunjukkan bahwa di akhir tahun 2013 terdapat sebanyak 35 juta (33,2 - 37,2 juta) orang hidup dengan HIV di seluruh dunia dan sebanyak $50 \%$ di antaranya adalah perempuan dan 2,1 juta anak berusia kurang dari 15 tahun. ${ }^{1,2}$ Data kasus infeksi HIV/AIDS di Indonesia periode 1 Januari 1987-31 Desember 2010 adalah 24.131 kasus, dengan jumlah kematian sebesar 4.539 orang. Di Indonesia sendiri saat ini dilaporkan kasus baru HIV terakhir di tahun 2014 sebanyak 22.869 dengan jumlah kumulatif dari sejak pertama kali ditemukan di tahun 1987 sebesar 150.296 kasus. Bali termasuk di peringkat ke-3 setelah Papua dan Papua Barat dengan prevalensi 109,52 per 100.000 penduduk. Terhitung jumlah perempuan yang hidup dengan AIDS sebesar 30\% dan data transmisi perinatal diketahui sejumlah 1.506 kasus. Menurut faktor risiko penularan infeksi HIV/AIDS, jumlah kasus terbanyak adalah pada heteroseksual (12.717 kasus), pemakai narkoba suntik (9242 kasus), homoseksual (724 kasus), tranfusi darah (48 kasus), dan 628 kasus pada masa perinatal. $^{3}$

Upaya mencegah perkembangan infeksi HIV/AIDS di Indonesia sejalan dengan strategi Pemerintah Republik Indonesia yang tertuang dalam Milleneum Development Goals (MDGs), di mana target yang keenam adalah memerangi HIV/AIDS, malaria, dan penyakit menular lainnya. Upaya pencapaian target penurunan kejadian HIV/AIDS tertuang ke dalam tujuh strategi utama. Salah satu strategi tersebut adalah penguatan atau pengembangan sistem informasi dan surveilans. ${ }^{3}$ Implementasi dari penguatan atau pengembangan sistem informasi dan surveilans adalah tersedianya data tentang karakteristik epidemiologi infeksi HIV/AIDS. ${ }^{4}$

Terdapat beberapa karakteristik epidemiologi ibu hamil terinfeksi HIV yang juga meningkatkan risiko penularan. Umur merupakan salah satunya. Pada kasus ibu hamil terinfeksi HIV memiliki kecenderungan diderita oleh ibu hamil umur muda (di bawah umur 35 tahun). ${ }^{5}$ Tingkat pendidikan rendah akan mempersulit memperoleh pekerjaan dengan penghasilan yang layak. ${ }^{4}$ Untuk mencukupi kebutuhan yang beragam, akan timbul upaya memperoleh penghasilan lebih dengan berbagai cara. Penyalahgunaan narkoba dan berbagai bentuk prostitusi merupakan salah satu bentuknya. ${ }^{4} \mathrm{Hal}$ ini akan semakin mendekatkan wanita usia reproduksi pada risiko terinfeksi HIV. Lebih jauh lagi jika wanita tersebut hamil, tentu saja risiko penularan akan meluas kepada bayi yang dikandung.

Tampak bahwa karakteristik epidemiologi merupakan suatu data yang sangat penting di dalam mempelajari distribusi infeksi HIV dan faktor-faktor yang mempengaruhi distribusi tersebut. Sejalan dengan hal tersebut, karakteristik epidemiologi juga merupakan modal utama dalam penyusunan berbagai upaya pencegahan infeksi HIV.

Berdasarkan paparan tersebut di atas, melalui penelitian ini akan dilakukan pengumpulan data mengenai karakteristik ibu hamil dengan HIV. Penelitian ini diharapkan menjadi masukan atau tambahan pemikiran bagi petugas kesehatan dan para pemegang kebijakan dalam rangka mendukung upaya pencegahan penularan infeksi HIV pada perempuan dan lebih khusus lagi dari ibu hamil kepada bayinya.

\section{METODE}

Penelitian ini merupakan suatu penelitian deskriptif retrospektif, Penelitian ini dilaksanakan di Bagian Kebidanan dan Penyakit Kandungan Fakultas Kedokteran Universitas Udayana/RSUP Sanglah Denpasar, poliklinik PMTCT (Prevention of Mother-to-Child HIV Transmission) Rumah Sakit Umum Pusat Sanglah Denpasar dan Klinik VCT (Voluntary Counseling and Testing) Rumah Sakit Umum Pusat Sanglah Denpasar. Waktu penelitian dilaksanakan mulai Januari 2014 sampai dengan Desember 2017. Data yang diperoleh disusun dan diolah dengan menggunakan program SPSS versi 25.0, kemudian disajikan dalam bentuk tabel dan naratif. Data yang diperoleh dalam penelitian ini dianalisis secara deskriptif mengenai prevalensi ibu hamil dengan HIV, karakteristik ibu hamil dengan HIV, gambaran klinis ibu hamil dengan HIV, serta cara persalinan dan luaran janin ibu hamil dengan HIV di Rumah Sakit Umum Pusat Sanglah Denpasar.

\section{HASIL PENELITIAN}

Dalam kurun waktu 4 tahun dari tanggal 1 Januari 2014 sampai 31 Desember 2017 tercatat 218 kasus kehamilan dengan HIV yang didapatkan dari buku register poli klinik PMTCT RSUP Sanglah 
Tabel 1 Prevalensi Ibu Hamil dengan HIV di RSUP Sanglah Denpasar

\begin{tabular}{lccc}
\hline Tahun & $\begin{array}{c}\text { Jumlah Ibu Hamil dengan } \\
\text { HIV }\end{array}$ & $\begin{array}{c}\text { Jumlah Total Ibu } \\
\text { Hamil }\end{array}$ & Persentase (\%) \\
\hline 2014 & 50 & 2035 & 2,45 \\
2015 & 52 & 1442 & 3,60 \\
2016 & 72 & 1222 & 5,89 \\
2017 & 44 & 1093 & 4,02 \\
Total & 218 & 5792 & 3,76 \\
\hline
\end{tabular}

Tabel 2 Karakteristik pasien hamil dengan HIV berdasarkan usia, tingkat pendidikan, paritas, faktor risiko, dan pekerjaan di Rumah Sakit Umum Pusat Sanglah Denpasar periode Januari 2014 - Desember 2017

\begin{tabular}{|c|c|c|}
\hline Variabel & Jumlah & Persentase (\%) \\
\hline \multicolumn{3}{|l|}{ Usia } \\
\hline 15-19 Tahun & 9 & 4,12 \\
\hline 20-29 Tahun & 124 & 56,80 \\
\hline 30-39 Tahun & 83 & 38,07 \\
\hline$>40$ tahun & 2 & 0,91 \\
\hline \multicolumn{3}{|l|}{ Tingkat Pendidikan } \\
\hline Rendah & 105 & 48,17 \\
\hline Menengah & 96 & 44,04 \\
\hline Atas & 17 & 7,79 \\
\hline \multicolumn{3}{|l|}{ Paritas } \\
\hline 0 & 79 & 36,23 \\
\hline 1 & 105 & 48,16 \\
\hline 2 & 29 & 13,30 \\
\hline 3 & 5 & 2,29 \\
\hline 4 & 0 & 0 \\
\hline \multicolumn{3}{|l|}{ Faktor risiko } \\
\hline Multipartner & 57 & 26,14 \\
\hline IDU + Heteroseksual & 3 & 1,37 \\
\hline IDU & 1 & 0,46 \\
\hline Suami IDU & 4 & 1,84 \\
\hline Suami Multipartner & 123 & 56,43 \\
\hline Suami Multipartner + IDU & 4 & 1,84 \\
\hline Suami dan Istri Multipartner & 15 & 6,88 \\
\hline Tidak mengetahui & 11 & 5,04 \\
\hline \multicolumn{3}{|l|}{ Pekerjaan } \\
\hline Ibu rumah tangga & 139 & 63,76 \\
\hline Swasta & 46 & 21,10 \\
\hline Villa/Hotel/Spa & 21 & 9,63 \\
\hline WTS & 1 & 0,45 \\
\hline Pedagang & 10 & 4,58 \\
\hline PNS & 1 & 0,45 \\
\hline
\end{tabular}

Denpasar. Dari seluruh jumlah kasus tersebut, kami mendapatkan jumlah kasus ibu hamil dengan HIV pada tahun 2014 sebanyak 50 kasus, pada tahun 2015 sebanyak 52 kasus, pada tahun 2016 sebanyak 72 kasus, dan pada tahun 2017 sebanyak 44 kasus sementara angka kejadian ibu hamil dengan HIV di RSUP Sanglah Denpasar dapat kami tampilkan dari tanggal 1 Januari 2014 sampai 31 Desember 2017 yaitu pada tahun (Tabel 1).

Pada penelitian ini didapatkan karakteristik usia pada ibu hamil dengan HIV paling dominan berada pada rentangan usia produktif yaitu 20-29 tahun (56,80\%), dengan paritas paling dominan adalah para $1(48,16 \%)$, faktor risiko paling dominan adalah suami multipartner $(56,43)$, dengan pekerjaan yang paling dominan adalah ibu rumah tangga (63,76\%) (Tabel 2).

Karakteristik berdasarkan asal daerah ditemukan Kabupaten Jebmbrana merupakan kabupate paling dominan $(20,64 \%)$, berdasarkan asal rujukan RSUD Jembrana merupakan rujukan yang paling dominan menuju RSUP Sanglah $(24,31 \%)$ (Tabel 3).

Karateristik berdasarkan usia kehamilan saat rujukan paling dominan pada usia $>28$ minggu kehamilan (47,70\%). Berdasarkan lama terapi ARV ditemukan durasi terapi lebih atau sama dengan enam bulan adalah yang paling dominan $(55,51 \%)$. Pasien dengan stadium klinis I adalah yang paling dominan dibandingkan dengan stadium klinis lainnya $(79,35 \%)$, dan tindakan yang terbanyak dilakukan di RSUP Sanglah adalah kelahiran dengan metode SC $(70,22 \%)$ (Tabel 4).

Berdasarkan luaran klinis berat lahir, paling dominan ditemukan dengan berat lahir $>2500$ gram $(82,58 \%)$, lebih banyak pasien yang mengalami anemia ringan $(\mathrm{Hb} 9,5-10,9 \mathrm{~g} / \mathrm{dL})(84,12 \%)$, berdasarka hasil deteksi vira load ditemukan bahwa lebih dominan pasien dengan viral load tidak terdeteksi $(66,7 \%)$, dan nilai hitung CD4 paling dominan berada pada $200-500 / \mathrm{mm}^{3}(49,08 \%)$ (Tabel 5).

\section{PEMBAHASAN}

Dari data yang kami peroleh kasus HIV terbanyak terjadi pada umur reproduktif yaitu 20-29 tahun. Berdasarkan laporan Departemen Kesehatan Republik Indonesia lebih dari 50\% kasus AIDS dilaporkan pada umur 15-29 tahun dan yang terbanyak pada umur 20-29 tahun. Prevalensi HIV pada perempuan di Indonesia sebesar $16 \%$, dan mayoritas $(92,54 \%)$ merupakan usia reproduksi aktif (15-35 tahun). ${ }^{6}$ Pada penelitian yang dikerjakan di Malawi, diketahui bahwa puncak insiden ibu hamil terinfeksi HIV adalah pada usia 26-30 tahun. ${ }^{7}$ 
Tabel 3 Karakteristik pasien hamil dengan HIV berdasarkan asal daerah da nasal rujukan di Rumah Sakit Umum Pusat Sanglah Denpasar periode Januari 2014 - Desember 2017

\begin{tabular}{|c|c|c|}
\hline Variabel & Jumlah & Persentase (\%) \\
\hline \multicolumn{3}{|l|}{ Daerah Asal } \\
\hline Denpasar & 21 & 9,66 \\
\hline Badung & 13 & 5,96 \\
\hline Tabanan & 6 & 2,75 \\
\hline Gianyar & 15 & 6,88 \\
\hline Bangli & 13 & 5,96 \\
\hline Klungkung & 11 & 5,04 \\
\hline Karangasem & 32 & 14,67 \\
\hline Buleleng & 19 & 8,71 \\
\hline Jembrana & 45 & 20,64 \\
\hline Luar Bali & 43 & 19,72 \\
\hline \multicolumn{3}{|l|}{ Asal rujukan } \\
\hline VCT RSUP & 49 & 22,4 \\
\hline YKP & 9 & 4,12 \\
\hline Puskesmas & 4 & 1,83 \\
\hline SpOG & 6 & 2,75 \\
\hline RS Swasta & 17 & 7,79 \\
\hline Bidan & 2 & 0,91 \\
\hline RS Wangaya & 6 & 2,75 \\
\hline RSUD Badung & 3 & 1,37 \\
\hline RSUD Tabanan & 3 & 1,37 \\
\hline RSUD Bangli & 4 & 1,83 \\
\hline RSUD Klungkung & 12 & 5,50 \\
\hline RSUD Buleleng & 2 & 0,91 \\
\hline RSUD Jembrana & 53 & 24,31 \\
\hline RSUD Gianyar & 5 & 2,29 \\
\hline RSUD Kr. Asem & 26 & 11,92 \\
\hline RSAD & 7 & 3,21 \\
\hline Bukan rujukan & 5 & 2,29 \\
\hline
\end{tabular}

Hal ini disebabkan karena pada rentang usia tersebut sering terjadi pergaulan bebas dan banyak penyalahgunaan obat-obatan golongan narkotika injeksi sehingga meningkatkan resiko HIV pada golongan umur reproduktif. Dan rentang umur ini merupakan kelompok usia subur dimana kehamilan sebagian besar terjadi pada kelompok usia ini.

Pada penelitian yang dilakukan oleh Simanjuntak $\mathrm{dkk}^{8}$ didapatkan bahwa terdapat hubungan yang bermakna $(p<0,05)$ antara tingkat pendidikan dan HIV. Dimana semakin rendah tingkat pendidikan maka semakin tinggi risiko menderita HIV. Tingkat pendidikan memiliki pengaruh pada difusi dan perbedaan penyebaran HIV di populasi. ${ }^{4}$ Kondisi serupa juga terjadi di Kenya, di mana ibu hamil terinfeksi HIV, berlatar belakang pendidikan dasar. ${ }^{9}$
Hal ini erat kaitannya dengan pengetahuan kesehatan dan kesempatan untuk mencari pekerjaan.

Dibandingkan penelitian yang dilakukan dari tahun 2010 sampai dengan 2013, menunjukkan bahwa penyebaran HIV terbanyak bukan berasal dari Denpasar lagi, ini menunjukkan bahwa HIV telah menyebar diseluruh kabupaten di Bali. ${ }^{10}$

Situasi epidemi HIV juga tercermin dari hasil Estimasi Populasi Rawan tertular HIV tahun 2012, diperkirakan ada 13,8 juta orang rawan tertular HIV dengan jumlah terbesar pada sub-populasi pelanggan pekerja seks yang jumlahnya lebih dari 6 juta orang dan pasangannya sebanyak hampir 5 juta orang. Pasangan pelanggan perempuan pekerja seks yang jumlahnya hampir 5 juta (35\%) ini, sebagian besar adalah ibu rumah tangga yang berisiko juga tertular HIV tanpa disadarinya.

Dari data yang kami dapatkan penularan yang banyak terjadi karena hubungan seksual yang tidak aman dan berganti-ganti pasangan (heteroseksual) baik oleh ibu hamil sendiri atau oleh pasangannya. Cara penularan ini sesuai juga dengan data dari Komisi Penaggulangan AIDS Propinsi Bali dari tahun 1987-2013 di Bali menurut faktor risiko penularan infeksi HIV/AIDS, jumlah kasus terbanyak adalah pada Multipartner (77,48\%) dan IDU $(10,16 \%)$.

Pekerjaan memiliki pengaruh pada perbedaan penyebaran HIV di populasi. Poundstone dkk. ${ }^{4}$ menyatakan bahwa pendapatan masyarakat merupakan prediktor terkuat dalam peningkatan kasus AIDS. Diketahui pada penelitian yang dikerjakan di Barbados bahwa hampir sebagian besar ibu hamil dengan HIV/AIDS adalah tidak bekerja. Hal yang sama juga terjadi di Malawi, di mana sebagian besar ibu hamil terinfeksi HIV adalah tidak bekerja. ${ }^{7}$ Hal ini disebabkan oleh besarnya faktor risiko status infeksi suami. Dengan tingginya faktor risiko yang berasal dari suami memberikan penjelasan bahwa walaupun pekerjaan ibu hamil tersebut tidak berkaitan dengan perilaku berisiko, ibu hamil tersebut memiliki risiko yang besar untuk terinfeksi HIV yang diidap oleh suami mereka. Hal ini berkaitan dengan masalah gender, kekuatan yang dimiliki perempuan itu sendiri dalam rumah tangga, dan ketidaksetaraan yang terjadi dalam rumah tangga. ${ }^{11}$

Kasus terbanyak merupakan partitas 1 ini sesuai dengan hasil penelitian kami berdasarkan kelompok umur dimana terbanyak merupakan perempuan dengan rentang umur 20-29 tahun, dimana rentang usia ini merupakan usia subur.

Kasus ibu hamil dengan HIV ini sebagian besar merupakan kasus rujukan dikarenakan program PMTCT belum tersebar diseluruh kabupaten di Bali. Sehingga pasien dirujuk ke poliklinik PMTCT RSUP Sanglah untuk pengawasan dan penanganan 
Tabel 4 Karakteristik pasien hamil dengan HIV berdasarkan usia kehamilan, lama terapi ARV, stadium klinis, dan tindakan di Rumah Sakit Umum Pusat Sanglah Denpasar periode Januari 2014 - Desember 2017

\begin{tabular}{lcc}
\hline Variabel & Jumlah & Persentase (\%) \\
\hline Umur Kehamilan & & \\
$\quad$ 12 minggu & 61 & 27,98 \\
12-28 minggu & 53 & 24,31 \\
$\quad>28$ minggu & 104 & 47,70 \\
Lama terapi ARV & & \\
$\quad<6$ bulan & 72 & 33,03 \\
$\quad$ 6 bulan & 121 & 55,51 \\
Belum mendapat ARV & 25 & 11,46 \\
Stadium klinis & & \\
I & 173 & 79,35 \\
II & 23 & 10,55 \\
III & 6 & 2,75 \\
IV & 16 & 15,69 \\
Tindakan yang dilakukan & & \\
SC & 125 & 70,22 \\
SC + MOW & 44 & 24,71 \\
Spontan & 2 & 1,12 \\
Kuretase & 7 & 3,93 \\
\hline
\end{tabular}

Tabel 5 Karakteristik pasien hamil dengan HIV berdasarkan berat lahir anak, status anemia, viral load, dan htung CD4 di Rumah Sakit Umum Pusat Sanglah Denpasar periode Januari 2014 - Desember 2017

\begin{tabular}{lcc}
\hline Variabel & Jumlah & Persentase (\%) \\
\hline Berat lahir & & \\
$\quad<500$ gram & 7 & 3,93 \\
500-1000 gram & 1 & 0,56 \\
1000-2500 gram & 23 & 12,92 \\
$\quad>2500$ gram & 147 & 82,58 \\
Status anemia & & \\
$\quad$ Anemia Ringan $(9,5-10,9 \mathrm{~g} / \mathrm{dL})$ & 106 & 84,12 \\
Anemia Sedang $(8-9,4 \mathrm{~g} / \mathrm{dL})$ & 17 & 13,50 \\
$\quad$ Anemia Berat $(7,9 \mathrm{~g} / \mathrm{dL})$ & 3 & 2,38 \\
Viral load & & \\
Tidak Terdeteksi & 34 & 66,67 \\
$<1000$ copies $/ \mathrm{ml}$ & 9 & 17,64 \\
$\quad>1000$ copies $/ \mathrm{ml}$ & 8 & 15,69 \\
Hitung CD4 & & \\
$>500 / \mathrm{mm}^{3}$ & 44 & 22,18 \\
200-500 $/ \mathrm{mm}^{3}$ & 107 & 49,08 \\
$50-200 / \mathrm{mm}^{3}$ & 54 & 24,77 \\
$<50 / \mathrm{mm}^{3}$ & 13 & 5,96 \\
\hline
\end{tabular}

kehamilan dan persalinan sehingga penularan HIV baik dari ibu ke bayi maupun dari ibu ke petugas kesehatan dapat dicegah.

Layanan ANC yang sangat luas di Indonesia dan cakupannya yang tinggi selama beberapa tahun terakhir ini merupakan modal dasar utama untuk melakukan PMTCT. Perlu segera dilakukan perluasan layanan PMTCT, terutama di wilayah dengan risiko tinggi HIV.

Data Kementrian Kesehatan menunjukkan dari 43.624 ibu hamil yang menjalani tes HIV, sebanyak $1.329(3,01 \%)$ ibu hamil dinyatakan positif HIV. Hasil pemodelan matematika epidemi HIV tahun 2012 menunjukkan prevalensi HIV pada ibu hamil diperkirakan akan meningkat dari 0,38\% (2012) menjadi $0,496 \%$ (2016) sehingga kebutuhan terhadap pelayanan PMTCT meningkat dari 12.189 (2012) menjadi 16.191 (2016). ${ }^{12}$

Dari 218 kasus, terbanyak dirujuk kepoliklinik PMTCT RSUP Sanglah pada trimester kedua dan ketiga untuk pengawasan kehamilan lebih lanjut dan untuk pemberian terapi anti retroviral untuk mencegah penularan dari ibu ke bayi. Ada beberapa faktor risiko yang meningkatkan kemungkinan bayi terinfeksi HIV. Yang paling mempengaruhi adalah viral load (jumlah virus yang ada di dalam darah ibunya). Oleh karena itu, salah satu tujuan utama terapi adalah mencapai viral load yang tidak dapat terdeteksi. Viral load penting pada waktu melahirkan. Risiko penularan akan lebih besar jika ibu memiliki viral load yang tinggi pada menjelang ataupun saat persalinan. Status kesehatan dan gizi ibu juga mempengaruhi risiko penularan HIV dari ibu ke bayi.

Dengan pemberian ARV selama minimal 6 bulan diharapkan viral load akan tak terdeteksi sehingga akan menurunkan risiko penularan dari ibu ke bayi. Sebanyak 61 kasus telah mendapatkan ARV saat umur kehamilan $\leq 12$ minggu, dikarenakan kasus telah diketahui HIV sebelum kehamilan dan telah mendapatkan ARV sebelum kehamilan. Sedangkan 25 kasus belum mendapatkan ARV sampai tindakan untuk mengakhiri kehamilan dilakukan karena kasus baru diketahui terinfeksi HIV pada trismester III menjelang tindakan akan dilakukan (kasus rujukan) ataupun kasus dimana belum diketahui status HIV saat tindakan dilakukan.

Temuan adanya mayoritas ibu hamil dengan HIV berada pada stadium I pada penelitian ini, menunjukkan bahwa sebagian besar penderita telah terjaring sejak awal dan mendapatkan penanganan lebih awal sehingga diharapkan hasil luarannya menjadi lebih baik.

Dari data yang kami dapatkan penentuan stadium klinis HIV ditentukan berdasarkan Kriteria WHO, dan didapatkan 78.34\% merupakan HIV 
stadium I. Kasus sebagian besar telah diketahui terinfeksi HIV sebelum kehamilan ataupun pasien yang hamil dengan faktor risiko yang kemudian dilakukan konseling VCT. Sehingga konseling dan pencegahan penularan dari ibu ke anak dapat optimal. Sedangkan pasien stadium III atau IV sebagian besar kasus mengalami keguguran ataupun persalinan preterm. Hal ini terkait dengan infeksi sekunder yang akan mempengruhi kehamilan.

Infeksi HIV sampai menimbulakan gejala AIDS memerlukan waktu kuarang lebih 8 tahun. Pada seseorang yang teinfeksi HIV ada masa Jendela/ window period merupaka masa dimana seseorang yang sudah terinfeksi HIV, namun pada pemeriksaan antibodi di dalam darahnya masih belum ditemukan/negatif. Masa jendela ini biasanya berlangsung 3 bulan sejak infeksi awal. ${ }^{13}$

Dari data yang kami dapatkan 125 kasus dilakukan seksio sesaria, hal ini sesuai dengan beberapa penelitian yang menyarankan bahwa seksio sesaria dapat memiliki efek yang penting dalam mengurangi kejadian transmisi HIV dari ibu ke anak, dan juga mengindikasikan bahwa dibandingkan cara persalinan lainnya seksio sesaria yang dilakukan sebelum persalinan dan sebelum pecah ketuban (seksio sesaria elektif) secara bermakna mengurangi kejadian transmisi HIV perinatal. Perempuan terinfeksi HIV harus disarankan seksio sesaria terjadwal untuk mengurangi kejadian transmisi jauh dari yang dapat dicapai hanya dengan terapi ZDV saja. ${ }^{14}$

Berdasarkan Permenkes RI nomor 51 tahun 2013 tentang Pedoman Pencegahan Penularan HIV dari Ibu ke Anak, jika terapi ARV dimulai pada minggu ke- 14 kehamilan (ARV > 6 bulan), persalinan pervaginam merupakan persalinan yang aman. Apabila tersedia fasilitas pemeriksaan viral load, dengan viral load $<1000 \mathrm{kopi} / \mu \mathrm{L}$, persalinan pervaginam aman dilakukan. Persalinan bedah sesar hanya boleh didasarkan atas indikasi obstetrik atau jika pemberian ARV baru dimulai saat usia kehamilan 36 minggu atau lebih, sehingga diperkirakan viral load $>1000 \mathrm{kopi} / \mu \mathrm{L}$.

Pada data penelitian ini dapatkan 23 kasus dengan berat badan lahir 1000-2500 gram, hal ini sesuai dengan kepustakaan yang menyatakan pada perempuan dengan HIV didapatkan sebesar $20 \%$ akan mengalami kelahiran prematur dan $24 \%$ mengalami PJT dan angka ini dapat lebih besar pada negara berkembang tentunya dengan hal ini maka secara tidak langsung akan meningkatkan morbiditas dan mortalitas perinatal. ${ }^{15}$

Pada penelitain di afrika selatan di dapatkan hampir dua pertiga (64\%) pasien hamil dengan HIV positif memiliki kadar hemoglobin kurang dari $11 \mathrm{~g} / \mathrm{dL}$ pada trimester ketiga, dan 11,8\% akan terjadi anemia pada saat postpartum. Infeksi HIV bisa menyebabkan anemia melalui dari proses gangguan dari erythropoietin (EPO) dalam merangsang sumsum tulang, perubahan dari produksi dari cytokines sampai penggunaan obat obatan retroviral khususnya zidovudine. Kadar CD 4 yang rendah merupakan faktor resiko yang signifikan dalam terjadi anemia pada ibu hamil dengan HIV positif, terutama pada kadar kurang dari 200 cells $/ \mathrm{mm}^{3}{ }^{4}$

WHO merekomendasikan tablet suplemen tablet besi dan asam folat pada ibu hamil yang terinfeksi HIV dengan dosis $400 \mu \mathrm{g}$ folat dan $60 \mathrm{mg}$ zat besi, dimana pada pengobatan anemia memerlukan dosis dua kali dari dosis harian. ${ }^{16}$

Viral load merupakan salah satu prediktor utama dalam memperkirakan resiko transmisi HIV pada ibu ke anak. Pada study "Women and Infants Transmision study" (WITS) didapatkan data pada viral load kurang dari 1000 copies/ml tidak di dapatkan transmisi antara ibu ke bayi, dimana pada viral load lebih dari 100.000 copies/ml didapatkan transmisi sebesar $60 \%$. Kombinasi antara pemberian HAART (Highly Active Antiretroviral Therapy) dan tindakan sectio cesaria sebelum inpartu menurunkan angka transmisi sampai dengan $1 \%$, sedangkan pada viral load kurang dari 50 copies $/ \mathrm{ml}$ disertai dengan pemberian HAART dan tindakan sectio cesaria elektif memberikan angka transmisi sampai dengan $0,1 \%{ }^{17}$

Pada wanita dengan viral load 10.000 copies $/ \mathrm{ml}$ sampai dengan 100.000 copies/ml untuk mencapai kadar viral load kurang dari 50 sampai dengan kurang dari 1000 copies/ml pada usia 36-38 minggu memerlukan intervensi HAART pada usia kehamilan kurang dari 20 minggu. ${ }^{18}$

Kadar CD 4 kurang dari $500 / \mathrm{m}^{3}$ direkomendasikan untuk memulai terapi ARV karena memiliki resiko yang tinggi untuk terjadi infeksi kulit, infeksi paru dan infeksi TB walaupun infeksi oppurtunistik yang parah seperti Pneumocystis Pneumonia (PCP), Mycobacterium Avium Complex (MAC) dan Cytomegalovirus (CMV) jarang terjadi. Pada kadar CD 4 antara $50-200 / \mathrm{m}^{3}$, resiko untuk terjadi infeksi oppurtunistik semakin meningkat, dan jika sampai di bawah $100 / \mathrm{m}^{3}$, pemberian terapi untuk pencegahan infeksi jamur perlu diberikan. Di Amerika Serikat semua pasien yang memiliki keluhan dan gejala infeksi tanpa memandang dari jumlah dari CD 4 atau jumlah viral load perlu mendapatkan terapi ARV. WHO sendiri menganjurkan untuk memberikan terapi inisiasi ARV pada semua stadium tanpa memandang kadar CD 4. ${ }^{18,19}$

\section{SIMPULAN}

Simpulan pada penelitian ini Rumah Sakit Umum Pusat Sanglah didapatkan dalam kurun waktu 4 tahun (1 Januari 2014 - 31 Desember 2017) 
tercatat 218 kasus kehamilan dengan HIV, mayoritas pada pada umur 20-29 tahun, tingkat pendidikan rendah, pekerjaan ibu rumah tangga, 139 kasus $(63,76 \%)$, berasal dari Jembrana, dengan faktor risiko suami yang heteroseksual (multipartner seksual), dengan usia kehamilan $>28$ minggu, berada pada stadium klinis I, dilakukan tindakan lahir melalui metode SC, melahirkan bayi dengan berat lahir > 2500 gram, mengalami anemia ringan, memiliki nilai viral load yang tidak terdeteksi, dan memiliki hitung CD4 200-500/ $\mathrm{mm}^{3}$.

\section{KONFLIK KEPENTINGAN}

Penulis menyatakan tidak terdapat konflik kepentingan terkait publikasi dari artikel ini.

\section{PENDANAAN}

Penelitian ini tidak mendapatkan bantuan dana dari pemerintah ataupun sektor swasta lainnya.

\section{ETIKA DALAM PENELITIAN}

Seluruh pasien telah mendapatkan informed consent terkait publikasi dari data rekam medis pada jurnal ilmiah kedokteran.

\section{DAFTAR PUSTAKA}

1. Kementrian Kesehatan Republik Indonesia. Pedoman Nasional Pencegahan Penularan HIV Dari Ibu Ke Anak (PPIA). Edisi kedua; 2012

2. WHO. 2015. Global Health Observatory (GHO) data: Number of people (all ages) living with HIV. World Health Organization. (serial online), [cited 2015 June 2015] Available from: URL: www.who.int/gho/hiv/ epidemic_status/cases_all_text/en/

3. Kementerian Kesehatan Republik Indonesia. Statistik Kasus HIV/AIDS di Indonesia. Kementarian Kesehatan Republik Indonesia. 2011; (artikel online), [dikutip 23 Februari 2011]. diunduh dari: URL: http://spiritia.or.id/ Stats/StatCurr.pdf

4. Poundstone KE, Strathdee SA, Celentano DD. The social epidemiology of human immunodeficiency virus/acquired immunodeficiency syndrome. Epidemiol Rev. 2004;26:2235. doi:10.1093/epirev/mxh005.

5. Sagay AS, Kapiga SH, Imade GE, Sankele JL, Idoko J, Kanki P. HIV infection among pregnant women in Nigeria. International Journal of Gynecology \& Obstetrics. 2005; 90(1):61-67.

6. Pratomo H, Djauzi S, Naing AM, Anwar AD, Besar DS, Setiabudi D, Resmiati F. Faktor Risiko Penularan HIV Dari Ibu Ke Bayi. dalam: Pratomo, H., editor. Pedoman Nasional Pencegahan Penularan HIV Dari Ibu Ke Bayi. Departemen Kesehatan Republik Indonesia: Direktorat Jenderal Bina Kesehatan Masyarakat. 2006; h. 13-18.
7. Kwiek JJ, Mwapasa V, Alker AP, et al. Socio-demographic characteristics associated with HIV and syphilis seroreactivity among pregnant women in Blantyre, Malawi, 20002004. Malawi Med J. 2008;20(3):80-85. doi: $10.4314 / \mathrm{mmj}$. v20i3.10965

8. Simanjuntak M, Bukit LM. Dimensi budaya dan penyebaran penyakit HIV/AIDS di perkumpulan kasih rakyat. Perspektif Sosiologi. 2015;3(1):90-103.

9. Kiptoo M, Mpoke S, Ng'anga Z, Mueke J, Okoth F, Songok E. Survey on prevalence and risk factors on HIV-1 among pregnant women in North-Rift, Kenya: a hospital based cross-sectional study conducted between 2005 and 2006. BMC Int Health Hum Rights. 2009;9:10. Published 2009 Apr 30. doi: 10.1186/1472-698X-9-10.

10. Sudewa SPA. Prevalensi dan Karakteristik Ibu Hamil Dengan HIV di Rumah Sakit Umum Pusat Sanglah Denpasar dalam periode tahun 2010 - 2013. [Deskriptif]. Universitas Udayana: Denpasar; 2014.

11. Naidoo Y. South African Indians and HIV/AIDS: towards an understanding of HIV transmission dynamics in the Chatsworth community. (serial online). 2008. [cited 2014 Mar. 11]. Available from: URL: www.hsrc.ac.za/research/ output/5494_Naidoo_SAIndiansandHIVAIDS.pdf

12. Kementerian Kesehatan Republik Indonesia. Statistik Kasus HIV/AIDS di Indonesia. Kementarian Kesehatan Republik Indonesia. (artikel online). 2017. [dikutip 23 Februari 2011]. diunduh dari: URL: http://spiritia.or.id/ Stats/StatCurr.pdf

13. Depkes RI. Analisis Kecenderungan Perilaku Berisiko Terhadap HIV Di Indonesia: Laporan Survei Terpadu Biologis dan Perilaku Tahun 2007. Jakarta Pusat; Subdit AIDS \& PMS Dit. P2ML Ditjen PP \& PL Departemen Kesehatan.

14. Minkoff HL. Prevention of mother-to-child transmission of HIV. Clinical Obstetrics and Gynecology. 2011;44: 210-225.

15. Cunningham FG, Leveno KJ, Bloom SL, Hauth JC, Rouse DJ, Spong CY. 2014. Human Immunodeficiency Virus (HIV) Infection. In: Twickler D, Wendell G, editors. Williams Obstetrics. 23rd. Ed. United States of America: McGraw-Hill. p. 1246-1253.

16. Gangopadhyay R, Karoshi M, Keith L. Anemia and pregnancy: A link to maternal chronic disease. International Journal of Gynecology \& Obstetrics. 2011; 115 (Supplement 1): S11-S15.

17. Townsend C, Schulte J, Thorne C, et al. Antiretroviral therapy and preterm delivery-a pooled analysis of data from the United States and Europe. BJOG. 2010;117(11):13991410. doi: $10.1111 /$ j.1471-0528.2010.02689.x

18. Working Group on Modelling of Antiretroviral Therapy Monitoring Strategies in Sub-Saharan Africa, Phillips A, Shroufi A, et al. Sustainable HIV treatment in Africa through viral-load-informed differentiated care. Nature. 2015;528(7580):S68-S76. doi: 10.1038/nature16046

19. Negara I, Anantasika A, Putra A, Wiradnyana A, Tunas I. Characteristics of Pregnant Women with HIV Infection Following Prevention of Mother to Child Transmission of HIV (PMTCT) Program in Sanglah General Hospital 2005-2014. Bali Medical Journal. 2016;5(1):147-151. DOI: 10.15562/bmj.v5i1.291

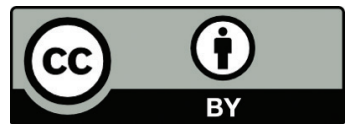

This work is licensed under a Creative Commons Attribution 